dit wel het geval: studenten van de experimentele groepen scoorden hoger op de inhoudsgebonden summatieve toetsen dan de studenten van de controlegroepen.

Sluijsmans geeft aan dat verder onderzoek wenselijk is en doet de volgende aanbevelingen voor onderwerpen van toekomstig onderzoek:

- de effecten van een langere trainingsperiode op de peer assessmentvaardigheden;

- het ontwerpen van modules waarbij de peerassessmenttraining nog meer verweven wordt met de verwerving van de inhoudsgebonden vaardigheden;

- extra onderzoek naar de invloed van vakinhoud op de relatie tussen beoordelingsvaardigheden en inhoudsgebonden vaardigheden.

Natuurlijk is verder onderzoek van groot belang. Maar ook nu al kunnen we van dit onderzoek het een en ander leren voor de praktijk van het ontwikkelen van een studentgericht curriculum. Het gaat hier om het verwerven van reflectieve vaardigheden. Sluijsmans bepleit hierbij deze vaardigheid niet geïsoleerd aan te bieden, maar juist in te bedden in de context van het verwerven van inhoudsgebonden vaardigheden. Verder leert zij ons dat een training hierbij essentieel is: beoordelingsvaardigheden zijn complex en ook deze vaardigheden moet de student leren. Een van de studenten gaf ook aan "I never realised that assessing the work of a peer is so difficult". Het beoordelen van de ander moet ook gezien worden in het kader van de toekomstige beroepsvoorbereiding. Ook in de beroepspraktijk is het van belang de ander van goede feedback te kunnen voorzien. Gezien het belang van reflectie is het mijns inziens wenselijk deze vaardigheid door de hele studie heen te verwerken, soms in de vorm van peer assessment, soms als self-assessment of bijvoorbeeld als reflectieverslag in een portfolio. Als dit leidt tot hogere inhoudsgebonden resultaten is dit meegenomen, maar als een student er 'alleen' meer inzicht door krijgt in eigen werk en goede feedback kan geven aan collega's, dan is dit wat mij betreft voldoende effect om er veel belang aan te hechten.

Jacqueline Hoogenboom

Coördinator centre of excellence competentiegericht onderwijs

Hogeschool INHOLLAND Rotterdam

\section{Portfolio is in de mode}

\author{
Driessen E, Beijaard D, Tartwijk J van, Vleuten \\ CPM van der, redactie. Portfolio's. Hoger On- \\ derwijs Reeks. Groningen: Wolters-Noordhoff; \\ 2002. 150 pp. ISBN 90-01-85101-0. €24,50.
}

Onderwijs gericht op het ontwikkelen van bekwaamheid, in een 'outcome' of 'competencebased' curriculum, vraagt om een andere aanpak van zowel leren als beoordelen dan onderwijs gericht op kennis. De medische student moet bekwaamheid verwerven op verschillende terreinen: communicatie, probleemoplossen, omgaan met kennis en wetenschap, onderzoeken, behandelen, omgaan met de maatschappelijke context, reflecteren. ${ }^{1}$

Niet al deze zeven terreinen zijn even goed te verkennen met behulp van een portfolio. Op het eerste gezicht is een portfolio vooral geschikt voor het volgen van persoonlijke ontwikkeling, voor reflectie op medisch handelen, eigen functioneren en attitude, en begrip van morele en juridische verantwoordelijkheden. Maar er zijn meer mogelijkheden. ${ }^{2}$ Educatieve en selectieve beoordeling op het gebied van bekwaamheid is lastig en niet altijd objectief en effectief. Of een portfolio hierin verbetering kan brengen, is een onderzoek waard, en het boek 'Portfolio's' is hiervoor een goed uitgangspunt.

De redacteuren, werkzaam aan universitaire leraren- en docentenopleidingen in Leiden en Utrecht en aan de medische faculteit van Maastricht, lieten zich bijstaan door auteurs met kennis van zaken uit diverse hbo-opleidingen waar al wat langer (5-10 jaar) ervaring is opgedaan met portfolio's. Met het boek hopen de auteurs de lezers te behoeden voor wat zij noemen de "portfolioparadox": portfolio's lijken een panacee, maar de praktijk is weerbarstig en teleurstelling onvermijdelijk. Het fenomeen 'portfolio-folly' werd onlangs beschreven in de kolommen van dit tijdschrift: "een opgeblazen airbag". ${ }^{3} \mathrm{U}$ bent gewaarschuwd!

In het eerste hoofdstuk wordt de korte geschiedenis van het portfolio beschreven. Ook wordt ingegaan op de mogelijkheden en moeilijkheden van toepassing in het hoger onderwijs. Een portfolio kan goed helpen bij "het bespreekbaar maken van de individuele leerweg van de student".

In hoofdstuk 2 tot en met 5 zijn ervaringen beschreven uit drie hbo-opleidingen en onder eerstejaars geneeskundestudenten in Maastricht. Gedetailleerde voorbeelden worden gege- 
ven van verplichte en vrij te bepalen opdrachten (bewijsstukken) en van het gebruik bij selectieve (geneeskunde, Maastricht) en educatieve beoordeling (small business \& retail management, Enschede).

Hoofdstuk 6 betreft het maatwerk dat een portfolio kan bieden ten behoeve van 'zij-instromers', en de (h)Erkenning van hoe-dan-ook Verworven Competenties (EVC). Het portfolio is bij uitstek het instrument voor het krijgen van inzicht in elders verworven competenties.

De mogelijkheden van een elektronisch portfolio worden toegelicht in vier hoofdstukken. Voor de medische opleiding lijken deze niet direct interessant, maar wie introductie ervan in het onderwijsprogramma overweegt, zoals in Edinburgh is gedaan, doet er goed aan de tips in hoofdstuk 10 te lezen en zich vervolgens te verdiepen in de beschrijving van zeven jaar ervaring in de postdoctorale lerarenopleiding en de professionaliseringstrajecten voor universitaire docenten te Utrecht (hoofdstuk 7). ${ }^{2}$ Elektronische portfolio's waren meer 'to the point' dan portfolio's op papier. Zij openen ook nieuwe mogelijkheden voor onderlinge discussies, iets wat in Amsterdam wekelijks gedaan wordt in Metawerkgroepen van vijftien personen (hoofdstuk 8). Het portfolio heeft dan een 'open' gedeelte.

Hoofdstuk 11 integreert de ideeën en ervaringen van de auteurs en geeft antwoord op vragen: de aan portfolio inherente activiteiten en een "portfolio leeromgeving"; stimuleert het samenstellen van een portfolio tot reflectie? Is begeleiding daarbij nodig? Hoe is een prestatie op basis van een portfolio te beoordelen? Wat is de inhoud en de structuur van een portfolio bij gebruik als bewaker van het proces (reflectie) en van het product (beoordeling van andere bekwaamheden).

Het boek wordt afgesloten met een epiloog getiteld 'Portfolio invoeren?'

Mijn antwoord op deze vraag is: lees dan eerst dit informatieve boekje. Juist omdat het zich niet beperkt tot medisch onderwijs, waarover bijvoorbeeld in Medical Teacher al veel is te vinden.

\section{J.W. Briët}

onderwijscoördinator Geertruiden Ziekenhuis Deventer

\section{Literatuur}

1. Projectgroep G2010. Blauwdruk G2010; Herziening curriculum Geneeskunde. Groningen, Faculteit der Medische Wetenschappen; 2002.

http://coo.med.rug.nl/fmw/a30.htm.
2. Scottish Deans' Medical Group. The Scottish Doctor. Undergraduate learning outcomes and their assessment: a foundation for competent and reflective practitioners; 2002. www.scottishdoctor.org

3. Wachter J de. De portfolio-follies. Tijdschrift voor Medisch Onderwijs 2003;22(1):42.

\section{The script concordance test}

Charlin B. Standardized assessment of ill-defined clinical problems: The script concordance test [proefschrift]. Maastricht: Datawyse/ Universitaire Pers Maastricht, 114 pagina's. ISBN 9052783624.

Deze dissertatie beschrijft de script concordance test (SCT). Er wordt gerapporteerd over onderzoeken naar de theoretische en constructvaliditeit, betrouwbaarheid, de methode van scoren en de toepasbaarheid van deze test. De SCT is ontwikkeld om vaardigheid in het klinisch redeneren te beoordelen. Klinisch redeneren is onderdeel van de denk- en beslisprocessen die artsen in staat stellen adequaat te handelen, wanneer zij met een ziektegeval geconfronteerd worden. Dit wordt ook wel klinisch probleemoplossen genoemd. Klinisch probleemoplossen bestaat uit drie factoren: klinisch redeneren, domeinkennis en relevante vaardigheden, zoals sociale en medisch-technische vaardigheden. Kennis wordt veelal getoetst met meerkeuzevragen en vaardigheden met een stationsexamen (objective structured clinical examination). Maar met name het toetsen van vaardigheid in het klinisch redeneren is problematisch gebleken. Meerkeuzevragen bleken ongeschikt, patiëntencasus waren moeilijk te beoordelen, te inhoudsspecifiek, moeilijk te scoren, duur en niet efficiënt. Geschikter leek de 'key-feature approach', die vooral gericht is op de componenten die van wezenlijk belang zijn bij het oplossen van een klinisch probleem. Vanuit de cognitieve psychologie werd duidelijk dat het waardevoller is om de organisatie van kennis te meten dan alleen maar het niveau van kennis. Deze ontwikkelingen tezamen hebben geleid tot de script concordance test (SCT).

In hoofdstuk 1 wordt ingegaan op theoretische benaderingen van klinisch redeneren. De SCT is gebaseerd op de scripttheorie uit de cognitieve psychologie, die stelt dat medische kennis gestructureerd is in netwerken van kennis omtrent ziekteverschijnselen. In deze kennisnetwerken zijn verbanden opgeslagen tussen 